\title{
Uitgelezen variatie
}

Citation for published version (APA):

Tilanus, M. G. J. (2009). Uitgelezen variatie. Maastricht University. https://doi.org/10.26481/spe.20090320mt

Document status and date:

Published: 20/03/2009

DOI:

10.26481/spe.20090320mt

Document Version:

Publisher's PDF, also known as Version of record

\section{Please check the document version of this publication:}

- A submitted manuscript is the version of the article upon submission and before peer-review. There can be important differences between the submitted version and the official published version of record.

People interested in the research are advised to contact the author for the final version of the publication, or visit the DOI to the publisher's website.

- The final author version and the galley proof are versions of the publication after peer review.

- The final published version features the final layout of the paper including the volume, issue and page numbers.

Link to publication

\footnotetext{
General rights rights.

- You may freely distribute the URL identifying the publication in the public portal. please follow below link for the End User Agreement:

www.umlib.nl/taverne-license

Take down policy

If you believe that this document breaches copyright please contact us at:

repository@maastrichtuniversity.nl

providing details and we will investigate your claim.
}

Copyright and moral rights for the publications made accessible in the public portal are retained by the authors and/or other copyright owners and it is a condition of accessing publications that users recognise and abide by the legal requirements associated with these

- Users may download and print one copy of any publication from the public portal for the purpose of private study or research.

- You may not further distribute the material or use it for any profit-making activity or commercial gain

If the publication is distributed under the terms of Article $25 \mathrm{fa}$ of the Dutch Copyright Act, indicated by the "Taverne" license above, 
Uitgelezen variatie 


\section{Colofon}

Foto omslag: MTI

Enter the barcode of life: Sharon Burggraaf - Daphna Isaacs

Ontwerp en print: Océ Business Services, Maastricht

ISBN: 978-90-5681-308-6

NUR: 876 specifieke geneeskunde

Alle rechten voorbehouden. Niets uit deze uitgave mag worden verveelvoudigd, opgeslagen in een geautomatiseerd gegevensbestand of openbaar gemaakt worden, zonder voorafgaande schriftelijke toestemming van de auteur of uitgever. 


\section{Uitgelezen variatie}

Maastricht, 20 Maart 2009

Prof. Dr. Marcel G.J. Tilanus 
Mijnheer de Rector Magnificus,

Dames en Heren,

\section{Historie}

Carolus Linnaeus, een Zweedse plantkundige, bioloog en arts, wat hetzelfde was in die tijd, introduceert een nomenclatuur systeem voor levende wezens. In 1753 publiceert hij zijn bekende werk Species Plantarum. Dit werk dient als startpunt voor een eenduidige indeling van het plantenrijk. Het boek beschreef alle toen bekende plantensoorten en is de basis geweest voor de huidige classificaties, waarbij de moleculaire DNA variaties de relaties tussen soorten hebben bevestigd, verfijnd, verbeterd en verduidelijkt. Zonder een eenduidige nomenclatuur voor communicatie en classificatie zal een Babylonische spraakverwarring U duidelijk zijn. In 1962 verdedigt Jon van Rood, Nederlandse arts en wetenschapper, zijn proefschrift "Leucocyte grouping", waarin hij op grond van samenklontering van witte bloedcellen, de agglutinatiereacties van antistoffen tegen leukocyten, deze leucocyten groepeert. Bij een bevalling in 1958 was een bloedtransfusie nodig vanwege complicaties. Binnen één uur na de transfusie ontwikkelde de vrouw een ernstige reactie op de bloedtransfusie. Omdat deze vrouw geen eerdere transfusies had gehad maar wel eerdere en meerdere zwangerschappen had doorlopen concludeert Van Rood dat zij agglutininen tegen de witte bloedcellen, leucocyt agglutininen, in haar bloed ontwikkeld had tegen de paternale antigenen van de foetus. Antistoffen aanwezig in het bloed van een persoon kunnen agglutineren met de leukocyten van een ander persoon. Afhankelijk van het type van deze agglutininen vindt er wel of geen reactie plaats. Zo konden de leucocyten in groepen ingedeeld worden. Van Rood noemt de groepen $4^{\mathrm{a}}$ en $4^{\mathrm{b}}$ op grond van hun reactie met verschillende sera verkregen van zwangere vrouwen met anti- $4^{a}$ en anti- $4^{b}$. Bloedsera van vrouwen met anti- $4^{a}$ reageren niet met hun eigen lymfocyten maar wel met de lymfocyten van de echtgenoot. Niet alleen groepeert hij de leukocyt agglutininen, maar bepaalt ook de frequentie van deze reacties in random geselecteerde donoren en stelt zo de genfrequentie van de groepen $4^{a}$ en $4^{b}$ vast. Voortschrijdend inzicht in de patronen van de agglutinatiereactie en de frequenties van de verschillende groepen toonde aan dat er meerdere onafhankelijk overervende groepen moesten zijn die voor de agglutinatie verantwoordelijk waren. Niet alleen de bepaling en definitie van de groepen, maar vooral de toepassing van deze kennis in de interne 
geneeskunde was cruciaal. Door internationale samenwerking konden meerdere agglutinatiegroepen worden gedefinieerd en sinds 1964 worden in internationale workshops de terminologie voor en functie van agglutinatiegroepen en hun varianten bepaald en onderzocht. Een eenduidige classificatie was geïntroduceerd. Deze naamgeving was de basis voor de nomenclatuur die nu met moleculaire bepalingen en biochemie verfijnd is. Het was het startpunt van de hedendaagse immunogenetica en immunologie: de studie naar de humane afweer tegen lichaamsvreemde pathogenen, de afweermechanismen die in het lichaam voorkomen tegen ziekteverwekkers en lichaamsvreemde stoffen. Gezien de algemene rol die de leukocyt agglutininen in het immuunsysteem spelen en hun voorkomen op de celmembraan van leucocyten werden zij hernoemd tot de Humane Leukocyt Antigenen, het HLA systeem. In de jaren 80 toonden biochemische en moleculaire analyses aan dat er 6 HLA genen zijn, die voor eiwitten coderen die direct betrokken zijn bij de immuunrespons op grond van de oorspronkelijke agglutinatiereacties. In de wandelgangen worden deze als klassieke HLA genen bestempeld.

Nu van het volledige humane genoom de base volgorde van het DNA bekend is, dat weergegeven wordt met de letters G, A, T en C zijn ongeveer 20.000 genen geïdentificeerd. Het DNA van het HLA gebied op chromosoom 6 bevat 4,6 miljoen nucleotiden. Vervolgens is van 8 personen de genomische sequentie van het HLA gebied bepaald en met elkaar vergeleken. Op basis van deze sequenties zijn 260 genen in dit gebied geïdentificeerd, waarvan er 160 voor een eiwit coderen, de functionele genen. Door vergelijking van deze sequenties zijn meer dan 44.500 variaties gevonden. Deze polymorfismen zijn overerfbare stabiele variaties, één letterveranderingen en deleties en inserties. De éénletterveranderingen, waarvan er ongeveer 37.500 gevonden zijn, worden single nucleotide polymorfismen (SNPs) genoemd en komen verspreid over het HLA gebied voor naast de ongeveer 7000 deletie en insertie polymorfismen (DIPS). De single nucleotide polymorfismen (SNPS) kunnen aanleiding geven tot eiwitveranderingen en in het HLA gebied zijn ongeveer 1200 van zulke coderende varianten van klassieke HLA genen geïdentificeerd. In de ImMunoGeneTics (IMGT) database zijn 3371 HLA varianten de dato 2 februari 2009 beschreven: 3371 HLA allelen op DNA gebaseerde polymorfismen. Bovendien worden in de databank 7 allelen genoemd met variaties die vertrouwelijk aan de nomenclatuurcommissie van de databank gerapporteerd zijn. 
De nomenclatuurcommissie zou deze niet moeten accepteren totdat deze publiekelijk beschikbaar zijn.

\section{Variatie / Polymorfisme}

Laat ik me eerst beperken tot de zogenaamde klassieke HLA genen, de 6 oorspronkelijk geïdentificeerde genen. De serologie bepaalt op grond van de agglutinatiereacties de groepen HLA antigenen op de leukocyten. Met de toepassing van moleculaire en biochemische benaderingen voor de karakterisatie van de genen en genproducten is de oorspronkelijke indeling op grond van DNA en eiwit gegevens verklaarbaar. In de loop van de tijd zijn de groepsdefinities verfijnd maar de oorspronkelijke nomenclatuur is blijven bestaan. Eerst werden de leucocyt antigene varianten toegeschreven aan één gen en de varianten opeenvolgend genummerd. Vervolgens werd duidelijk dat er twee verschillende genen waren en werd aan de leucocyt antigenen een locus toegekend. Zo ontstond de nomenclatuur humane leucocyt antigenen locus A en $B$, de huidige HLA-A en HLA-B genen. In de loop van de jaren werden op grond van de reactiepatronen van de serologische reacties met specifieke antistoffen subgroepen geïdentificeerd. Zo is bijvoorbeeld DR2 opgesplitst in DR15 en DR16 en afhankelijk van de laboratoriumbepaling kan deze onderverdeling wel of niet benoemd worden. Andere groepen en subgroepen werden op grond van cellulaire reacties bepaald. Deze serologische en cellulaire groepen vertegenwoordigen de functionele HLA specificiteiten; functioneel omdat deze leiden tot een immunologische reactie. De biochemie bevestigde de groepen en legde de link tussen de op DNA niveau geïdentificeerde genen, het eiwitproduct en de serologische en cellulaire reacties. DNA maakt de indeling op grond van variaties in het genoom: het polymorfisme. De verschillende methodes sluiten nauw op elkaar aan en leveren samen additionele informatie over de HLA antigenen die met serologie bepaald werden en de allelen die op basis van moleculaire bepalingen gekarakteriseerd waren.

De correlatie van DNA polymorfisme met de serologische reactiepatronen gaf de mogelijkheid om de in 1983 geïntroduceerde DNA polymerase ketting reactie (PCR) toe te passen voor het bepalen van de HLA variatie. Bovendien werd bekend dat een deel van het HLA molecuul direct betrokken was bij de immuunreactie. Fragmenten van lichaamsvreemde eiwitten, de peptiden, binden aan de groeve van het HLA molecuul en het HLA peptide complex wordt herkend door T 
cellen, die in het lichaam de immunologische reacties teweegbrengen. Om de serologische equivalenten op DNA te bepalen is slechts kennis van een deel van het DNA polymorfisme nodig. Dit concept is in de meeste gevallen waar, maar een Babylonische spraakverwarring is geïntroduceerd. Sommige laboratoria bepalen het polymorfisme van het hele gen, andere slechts delen van het gen of zelfs alleen specifieke polymorfismen. Het is duidelijk dat de variatie over het hele gen verspreid ligt. Slechts 257 van de 3371 bekende allelen zijn volledig in kaart gebracht.

$\mathrm{Nu}$ de moleculaire bepalingen eenvoudig kunnen worden toegepast zullen complete sequenties van de allelen bepaald moeten worden om de relatie tussen de verschillende allelen beter te kunnen begrijpen. De technologie is beschikbaar, we kunnen de HLA variatie in het genoom op nucleotiden niveau uitlezen en in kaart brengen. Bio-informatische analyses hebben een essentiële bijdrage geleverd om de associaties tussen genen, allelen en de definitie van haplotypes in ongerelateerde individuen te bepalen. De volgende stap is het begrijpen van de functie van het polymorfisme. De hedendaagse nomenclatuur is daarin verwarrend omdat de naam van een allel vaak slechts op een deel van de gensequentie gebaseerd is. Het polymorfisme van een allel is dus slechts ten dele bekend. Van de alleen op DNA niveau bepaalde nieuwe allelen is vaak onbekend wat het serologisch equivalent is en weten we niet welk polymorfisme van belang is in immunologische reacties. Verschillende studies hebben aangetoond dat één enkel aminozuurverschil tussen twee allelen een immunologische reactie teweeg kan brengen en andere studies laten zien dat veel aminozu urverschillen tussen allelen niet altijd tot een cellulaire immuunreactie zal leiden. Het is een uitgelezen kans om de HLA variatie, die nu volledig uitgelezen kan worden, op grond van de genoemde single nucleotide polymorfismen te bestuderen in relatie tot de immuun respons. Steeds meer publicaties geven aan welke aminozuren en combinatie van aminozuren, de zogenaamde epitopen, karakteristiek en voorspellend kunnen zijn voor immuunreacties. Een nieuwe nomenclatuur gebaseerd op SNP polymorfisme in plaats van de nomenclatuur gebaseerd op allelen, is de uitgelezen mogelijkheid om de HLA allelen functioneel te classificeren. Met behulp van "neural" netwerk algoritmes kunnen de serologische equivalenten van door DNA gedefinieerde HLA allelen bepaald worden. Een nomenclatuur gebaseerd op SNP polymorfismen kan beter dan de huidige nomenclatuur de overeenkomsten en verschillen tussen allelen weergeven. 
Verschillende allelen binnen een groep kunnen slechts één, maar ook vele aminozuren van elkaar verschillen. Polymorfismen in het ene allel kunnen in een andere combinatie in andere allelen voorkomen. Het is een uitdaging om alle eerdere definities in een nieuwe SNP nomenclatuur onder te brengen waarin functionele SNP en DIP epitopen herkenbaar zijn. Het eenduidig aangeven van functionele verschillen op basis van SNPs of combinaties van SNPs, de epitopen, die karakteristiek zijn voor aminozuren die immunologische reacties teweeg kunnen brengen, zal het begrip van HLA nomenclatuur in klinische toepassingen vergemakkelijken.

\section{Transplantatie}

HLA polymorfisme is van groot belang in transplantatie. Bij orgaantransplantatie zullen er HLA antigenen op het donororgaan aanwezig zijn die de patiënt als lichaamsvreemd herkent. De patiënt zal zijn immuunsysteem activeren om dit lichaamsvreemde materiaal af te stoten. Door levenslang afweeronderdrukkende medicijnen in te nemen zal de afstotingsreactie onderdrukt worden. Indien de patiënt eerdere contacten met vreemde HLA antigenen gehad heeft, bijvoorbeeld via bloedtransfusies, eerdere transplantaties of zwangerschappen, kunnen antilichamen tegen de lichaamsvreemde HLA antigenen gevormd zijn. Indien deze patiënten getransplanteerd worden met een donororgaan moet rekening gehouden worden met deze antilichamen. De patiënten worden vooraf gescreend of zij antistoffen hebben tegen HLA antigenen of niet. Bovendien wordt voor de transplantatie een serologische kruisproef uitgevoerd die aantoont of er antilichamen in de patiënt voorkomen die met het donororgaan reageren. Zijn er antistoffen aangetoond dan is het donororgaan niet geschikt voor de betreffende patiënt. HLA compatibiliteit, de overeenkomst van de HLA antigenen die de patiënt heeft ten opzichte van de HLA antigenen van de donor, verhoogt de transplantaatoverleving. Door de beperkte beschikbaarheid van donororganen en de grote variatie in HLA antigenen is het echter onmogelijk om primair op HLA overeenkomst te selecteren.

Als de patiënten antistoffen hebben, wordt bepaald tegen welke vreemde HLA antigenen zij antilichamen gevormd hebben. Voor de groep van patiënten die veel antistoffen hebben wordt ook andersom gekeken; tegen welke HLA antigenen heeft de patiënt geen antistoffen; een orgaan is geschikt als het orgaan die HLA antigenen heeft waartegen de 
patiënt geen antistoffen heeft. De definitie van HLA antigenen is hierbij van groot belang. Maar ook geldt dat hoe sneller getransplanteerd wordt hoe beter. Snel transplanteren zelfs met HLA verschillen, al dan niet met meer of minder immuunsuppressie, verbetert de transplantaatoverleving. De snelheid van de HLA typering en het aantonen van antistoffen in de patiënt tegen het donororgaan zijn essentieel. Dat is één van de redenen dat maar een beperkt deel van het polymorfisme bepaald wordt, namelijk het deel dat representatief is voor zijn allelgroepen. Op dit moment kan dit niet anders. Wel moeten we ons realiseren dat met deze grove wijze van typeren, de zogenaamde lage resolutie typering, veel specifieke informatie ontbreekt. Bovendien worden door verschillende centra soms slechts 3 of maar 4 van de 6 HLA genen getypeerd. Als een patiënt antistoffen heeft moet alsnog voor het ontbrekende locus getypeerd worden en dat vergt weer kostbare tijd. Technologische ontwikkelingen om de snelheid en volledigheid van typering te verhogen zonder verlies van resolutie en specificiteit is een continue uitdaging. Hetzelfde geldt voor antistofbepalingen waarbij de tegenwoordige technologie de specificiteit tot op epitoopniveau kan aangeven. Gezien de wachttijd en de beschikbaarheid van gespecificeerde antistofbepalingen zouden in ieder geval alle patiënten volledig op hoge resolutie niveau getypeerd moeten worden.

Er kan anders naar de HLA antigenen gekeken worden: namelijk naar de verschillende epitopen op het molecuul waartegen antistoffen gericht kunnen zijn. Een patiënt maakt geen antistoffen tegen zijn eigen epitopen, deze worden immers niet als lichaamsvreemd gezien. Als een donor beschikbaar komt, maar een ander HLA type heeft, wordt gekeken naar welke epitopen wel of niet overeenkomen. Duquesnoy heeft een algoritme ontwikkeld om de epitopen in plaats van de allelen te vergelijken. Ook al verschillen twee allelen, de gecombineerde epitopen van de HLA allelen van de patiënt kunnen overeenkomen. Het immuunsysteem van de patiënt herkent de donorepitopen niet als vreemd en maakt daar dus geen antistoffen tegen. Inzicht in de epitopen waartegen de antistoffen gericht zijn, biedt de mogelijkheid om hoog geïmmuniseerde patiënten toch met succes te transplanteren. De epitopen worden voorspeld uit de lage resolutie typering. Dat kan nu niet anders vanwege de tijd die hoge resolutie typeringen in beslag nemen en 24 uurs toepasbaarheid die nodig is voor orgaantransplantatie. Echter, snelle en adequate allelbepaling op grond van specifieke karakteristieke polymorfismen zijn van belang om de epitopen beter 
te karakteriseren. Door de introductie van dit acceptabele mismatch programma is de kans om voor hoog geïmmuniseerde patiënten een donor binnen enkele jaren te vinden, gestegen van 18\% naar 60\%. Deze Nederlandse benadering wordt geleidelijk overgenomen door andere landen.

De coördinatie van het uitwisselen van organen wordt door Eurotransplant gerealiseerd op grond van aan- en afwezigheid van antistoffen, HLA typering en wachttijd. De logistiek van typeren en het uitwisselen van organen behoeft verder Europees overleg en samenwerking. Het transport van een orgaan uit het buitenland naar bijvoorbeeld Nederland voor een urgente patiënt die mogelijk antistoffen heeft tegen het donororgaan, maar niet voor dat HLA locus in het buitenland getypeerd is, kan voorkomen worden door direct een volledige typering uit te voeren. Daarbij zal de kennis van de specificiteit van de antistoffen, in plaats van de aanwezigheid van antistoffen tegen brede HLA groepen, een grote bijdrage leveren voor de afweging van potentiële geschiktheid van het orgaan voor transplantatie naar een patiënt. De kosten en structuur voor deze benadering hoeven niet per se vele malen hoger te zijn, vooral als de efficiëntie van de logistiek en het gebruik van gedoneerde organen verbeterd kan worden met daaraan gekoppeld de kans op een succes van de orgaantransplantatie.

In het geval dat patiënten een stamcel- of beenmergtransplantatie als therapie voor hun ziekte nodig hebben, wordt allereerst gekeken of er familieleden zijn met identieke of nagenoeg identieke HLA typeringen. Met de tegenwoordige gemiddelde gezinsgrootte is de kans op een goede familiedonor afgenomen. Vrijwilligers die stamcellen willen doneren, zijn geregistreerd in donordatabanken. In de werelddatabank zijn alle donorbanken van de verschillende landen verzameld. In deze werelddatabank, de Bone Marrow Donors Worldwide, afgekort BMDW, zijn bijna 13 miljoen donoren opgeslagen waarbij Europdonor het centrale punt in Europa is. Helaas komt het veelvuldig voor dat zelfs binnen deze 13 miljoen donoren geen geschikte donor gevonden wordt. Van de ongerelateerde donoren wordt bekeken in welke mate de HLA allelen overeenkomen met de patiënten: de mate van matching. In internationale retrospectieve studies wordt bestudeerd welke matches en mismatches invloed hebben op het klinisch verloop. Ook hier blijkt dat snel transplanteren met een donor die met 9 van de 10 allelen van de patiënt overeenkomt, beter is dan lang te wachten op een 
geschikte donor waarvan alle 10 allelen overeenkomen, als zo'n donor überhaupt in de donorbank aanwezig is. De beschikbare donoren in de databank zijn op verschillende niveaus, lage en hoge resolutie, en in verschillende mate getypeerd. Soms is een beperkt aantal genen of zijn slechts delen van genen getypeerd, soms is de typering gebaseerd op serologische bepalingen. Dat is historisch zo gegroeid omdat al in de vroege zeventiger jaren de typeringen van vrijwillige stamceldonoren in een databank opgenomen zijn, die met de toen beschikbare methoden getypeerd zijn. Kennis van allelfrequenties en associaties tussen de verschillende loci kan de effectiviteit van de selectie van een geschikte donor voor een patiënt bevorderen. Essentieel hiervoor is de bestudering van variatie in verschillende populaties. Specifieke kennis over diversiteit in populaties en associaties tussen de verschillende HLA genen en HLA polymorfismen geven inzicht in de evolutionaire ontwikkeling van de HLA diversiteit. Niet alleen de migratie van volken is hierbij interessant maar de wetenschap van oud en van nieuw polymorfisme kan inzicht geven in de functionaliteit van het polymorfisme. De frequentie van allelen in verschillende populaties is van belang. Wij gaan er vanuit dat de $3371 \mathrm{HLA}$ allelen in de IMGT databank even belangrijk zijn. Toch zijn er allelen slechts één maal gevonden. In dit kader zijn de HLA allelen onder de loep genomen door een commissie van de American Society for Histocompatibility and Immunogenetics en is een aanbeveling voor een gewijzigde, klinisch vriendelijke nomenclatuur, "Common and welldocumented HLA alleles" uitgebracht. In deze aanbeveling worden allelen alleen apart vermeld als ze met frequenties hoger dan 0,1 \% of in tenminste 3 ongerelateerde individuen voorkomen. Daarnaast worden alle overigen allelen als zeldzaam geclassificeerd. Een nadeel van deze benadering is echter dat de indeling populatie afhankelijk is; allelen kunnen frequent gevonden worden in geïsoleerde populaties maar zeldzaam zijn in overige populaties. Een eenduidige klassificatie kan moeilijk zijn door het ontbreken van systematische studies van alle populaties.

De anthropologische component van de internationale workshop voor histocompatibility testing is een belangrijk onderdeel voor studies naar HLA polymorfisme in populaties. Degenen die deze studies als postzegelverzameling betitelen hoop ik overtuigd te hebben van het belang ervan. De kans is reëel aanwezig dat een patiënt een zeldzaam allel of zeldzame allelassociatie heeft en kennis waar de kans het grootst is om een gematchte donor te vinden kan van levensbelang zijn. 
Het volstaat dus niet om alleen naar de meest frequente allelen en haplotypes te kijken. Niet alleen zouden de bestaande databanken uitgebreid moeten worden, maar deze zouden bij voorkeur ook andere bevolkingsgroepen moeten bevatten, die allelen hebben die tot nu toe als zeldzaam worden beschouwd maar in hun populatie frequent blijken te zijn. Studies in populaties zijn van wezenlijk belang nu de natuurlijke menging der volken en rassen een nog grotere diversiteit teweeg brengt. Het nauwkeurig in kaart brengen van het allel polymorfisme, de frequenties en associaties van de verschillende HLA loci is noodzakelijk.

Bij de eerste stamceltransplantaties werden de stamcellen uit beenmerg geïsoleerd.Tegenwoordigwordenstamcellen uit het bloed vanvrijwilligers geïsoleerd na toediening van groeihormoon en hierdoor is de belasting voor de donor afgenomen. Sinds 1988 worden ook stamcellen voor transplantatiedoeleinden geïsoleerd uit navelstrengbloed. Commerciële instellingen propaganderen deze stamcellen op te slaan "voor later als je ze zelf nodig hebt". De kans dat een kind later als volwassene werkelijk gebruik zal maken van zijn eigen opgeslagen stamcellen, is uiterst gering. Door gebruik van stamcellen uit navelstrengbloed kunnen nu levens gered worden. Donorstamcellen kunnen uitgroeien tot verschillende gespecialiseerde bloedcellen en kunnen zich gemakkelijk in het beenmerg nestelen. De biologische karakteristieken van stamcellen uit navelstrengbloed ten opzichte van gemobiliseerde stamcellen uit perifeer bloed verschillen. Uit klinische gegevens blijkt dat het aantal HLA mismatches bij stamcellen geïsoleerd uit navelstrengbloed groter mag zijn dan bij stamcellen gemobiliseerd uit perifeer bloed zonder dat dit leidt tot meer transplantatie gerelateerde complicaties.

De stamcellen uit navelstrengbloed vormen een welkome aanvulling op het bestand van vrijwillig onverwante stamceldonoren. Dit navelstrengbloed is op een niet-commerciële wijze beschikbaar voor iedereen die voor een transplantatie met een onverwante donor in aanmerking komt. Een nadeel van navelstrengbloed is dat het slechts genoeg stamcellen bevat om een patiënt met een lichaamsgewicht van 30-40 kg te transplanteren. Tegenwoordig worden daarom meerdere navelstrengbloed units gecombineerd met goede transplantatie resultaten. In het concept dat iemand zijn eigen stamcellen uit navelstrengbloed zou bewaren voor eigen behandeling, is het aantal eigen ingevroren stamcellen hiervoor onvoldoende en zou met andermans stamcellen gecombineerd moeten worden om het aantal 
benodigde stamcellen per kilogram lichaamsgewicht te kunnen bereiken. Het voordeel van het gebruik van stamcellen uit navelstrengbloed bij onverwante transplantaties is dat door een mismatch van HLA in donorstamcellen de resterende tumorcellen opgeruimd kunnen worden. Een mismatch kan positief uitpakken. Het immuunsysteem van de donor is gericht op de vernietiging van eventueel achtergebleven kwaadaardige cellen. Indien de stamcellen voor jezelf bewaard worden zijn er geen verschillen in HLA en is het effect op de vernietiging van achtergebleven tumorcellen nul. Ook kunnen bij bepaalde vormen van leukemie in de stamcellen van het navelstrengbloed dezelfde afwijkingen aanwezig zijn die typisch zijn voor die vorm van leukemie. Deze stamcellen kunnen niet voor transplantatie gebruikt worden. Al met al genoeg redenen om navelstrengbloed te doneren ten behoeve van de patiënten die het nu nodig hebben en niet voor jezelf te bewaren. In Nederland bestaat de mogelijkheid om op medische indicatie zonder kosten stamcellen uit navelstrengbloed op naam op te slaan voor de eventuele behandeling van familiaire ziekten. Een hele andere ontwikkeling die de afgelopen 10 jaar belangrijke vorderingen heeft gemaakt is het onderzoek naar de basisprocessen van de ontwikkeling van embryonale stamcellen. De mogelijkheid deze stamcellen te kweken biedt nu screeningsmogelijkheden voor farmaceutisch onderzoek. Het zal echter nog jaren duren voordat embryonale stamcellen toegepast kunnen worden voor de behandeling van bijvoorbeeld neurologische ziekten zoals de ziekte van Parkinson. Een andere doorbraak op dit vakgebied is de ontdekking dat slechts vier transcriptie factoren volledig gedifferentieerde cellen kunnen re-programmeren tot een embryonaal stamcel stadium, de geïnduceerde pluripotente stamcel. De komende 10 jaar zullen deze veelbelovende richtingen van onderzoek nieuwe toepassingsmogelijkheden voor stamceltherapie bieden.

\section{Functionaliteit van polymorfisme}

Gelukkig is gebleken dat niet alle verschillen op DNA niveau ook leiden tot klinisch relevante verschillen. Niet elk verschil op DNA niveau leidt tot een immunologische afweerreactie. Ongeveer $35 \%$ procent van de patiënten die voor een behandeling met een stamcel transplantatie in aanmerking komt, heeft geen volledig gematchte donor. Met meer kennis over de toegestane mismatches, mismatches die geen immuunreactie opleveren, kan ook voor die patiënten een geschikte donor geselecteerd worden. Zoals geschetst zijn meer mismatches toegestaan in transplantaties 
met stamcellen uit navelstrengbloed. Onderzoek naar de mechanismen waarom is van groot belang om te begrijpen wat en hoe er gematcht moet worden. Of daarbij het ene HLA locus en gen belangrijker is dan een ander; ik denk het niet. Ook is het belang van een mismatch in HLA $A, B$ en/of $C$ in ongerelateerde stamceltransplantaties niet eenduidig; maar duidelijk is dat een klasse I of klasse II mismatch effect heeft op de transplantatie. Het gaat om de aan- en afwezigheid van epitopen op het HLA molecuul van de patiënt en donor. Mismatches op bepaalde posities in HLA klasse I moleculen kunnen complicaties in stamceltransplantatie teweeg brengen. McCluskey heeft in vitro aangetoond dat één aminozuurverschil een $\mathrm{T}$ cel respons kan initiëren. Andersom laat Heemskerk zien dat vele epitoopverschillen op het HLA molecuul geen aanleiding geven tot een immuunrespons. Deze preliminaire data moeten verder bestudeerd worden om ze in te kunnen passen in het algemene concept voor de selectie van donoren in stamceltransplantatie. Het aantal publicaties, waarbij specifieke verschillen en overeenkomsten binnen allelen verantwoordelijk geacht worden voor het wel of niet initiëren van een immuunrespons, neemt toe en deze studies krijgen meer en meer aandacht. De tijd dat een bepaald allel verantwoordelijk gesteld kon worden voor een immuunrespons is voorbij, epitopen of specifieke aminozuren karakteriseren de immuunrespons.

De HLA groepen zijn gedefinieerd op grond van de oorspronkelijke agglutinatiereacties. Nu we een groot deel van de diversiteit weten, hebben we de mogelijkheid om dit polymorfisme te bepalen in relatie tot functie. De klassieke HLA genen bevatten ongeveer 1200 eiwit coderende SNPs. Identificatie, en dus nomenclatuur, van een immuunrespons op basis van deze SNPs is mogelijk. Gezien de diversiteit van HLA zal dit alleen in internationale samenwerking kunnen en derhalve zijn internationale workshops nog steeds relevant en niet achterhaald.

Ik vertelde $U$ dat er vele SNPs in het DNA voorkomen, maar dat slechts 1200 van de 44.500 SNPS in het HLA gebied coderen voor een ander aminozuur. Naast die 1200 zijn er nog andere SNPs die ook een effect hebben op een immuunfunctie. SNPs kunnen genen inactiveren of aanleiding geven tot alternatieve splice vormen van RNA. Eén van mijn AIO's heeft een DNA polymorfisme in een HLA allel geïdentificeerd dat geen verandering geeft van aminozuren in het molecuul. Echter RNA analyses toonden aan dat het DNA polymorfisme aanleiding gaf tot een RNA splice variant, die geen herkenbaar functioneel eiwit opleverde, een 
zogenaamd nul allel. Op grond van deze bepalingen, die bevestigd zijn met eiwitanalyses is één van de eerste splice varianten, waarvan het HLA molecuul ontbreekt, bewezen.

Alternatievesplicing is geen uitzondering maar eerder een regel. Sequentie analyses en micro-array RNA profielen tonen aan dat ten minste tweederde van de humane genen alternatieve splice producten kunnen vormen, die naast het normale RNA voorkomen. Eén gen in het DNA kan meerdere vormen van RNA opleveren en daardoor weer verschillende eiwitten. In het micro-array RNA profiel van chromosoom 6 komen 1267 splice varianten voor, waarvan er 523 coderen voor een alternatief product. Alternatieve splice producten, die afwijkend zijn van de normale eiwitten, kunnen leiden tot ziekten. Ook in transplantatie kunnen splice varianten aanleiding geven tot een veranderde immuunrespons.

Preliminaire studies in hoofd/halstumoren geven aan dat HLA splice vormen specifiek in deze tumoren voorkomen en zo ontsnappen aan de immuunrespons. Eén van de studenten heeft alle beschikbare volledige HLA sequenties bestudeerd en de vele potentiële alternatieve splice sites aangegeven. Veel meer RNA gebaseerde studies zijn noodzakelijk om de consequenties van de additionele variatie die door RNA veroorzaakt wordt te onderzoeken. Een mooi voorbeeld is de karakterisatie van een biomarker panel met behulp van RNA micro-array profielen dat geassocieerd is met tolerantie voor een getransplanteerde nier. De expressie van 49 genen in het bloed van getransplanteerde patiënten geven een patroon, een footprint, die gecorreleerd is met minder afstoting. Nadere studies moeten uitwijzen of deze markers in de praktijk kunnen dienen als leidraad voor de reductie van de immuunsuppressie medicatie.

Een andere klasse van relevante SNPs wordt bepaald in de pharmacogenetica; de studie van effecten van genen en variatie van genen op de manier hoe het lichaam medicijnen metaboliseert. Genetische varianten kunnen de werking van medicijnen beïnvloeden. Een beperkte absorptie van een medicijn door een SNP polymorfisme zal het effect van dat medicijn reduceren. SNPs kunnen de afbraak van medicijnen beïnvloeden en zo op individueel niveau aanleiding geven tot hoge en lage responsen tegen die medicijnen. SNP polymorfisme in de target moleculen kan de binding en effectiviteit van de medicijnen beïnvloeden. Cytochroom p450 polymorfisme en respons op het medi- 
cijn metabolisme is hiervan een voorbeeld. De overgevoeligheid voor abacavir in de behandeling van HIV patiënten wordt niet alleen bepaald door het HLA allel maar juist door een bepaalde SNP variatie in het allel.

\section{Orgaan- en stamceldonatie}

Transplantatie Immunologie valt of staat met klinisch toegepaste transplantaties. Alle theorieën en fundamenteel onderzoek kunnen alleen maar toegepast worden als er transplantaties plaatsvinden waardoor er retrospectieve analyses mogelijk zijn. De patiënten die bereid zijn hun gegevens beschikbaar te stellen voor wetenschappelijk onderzoek, en daarvoor extra bloed of weefsel willen geven wil ik bij deze bedanken omdat onderzoek en ontwikkelingen anders niet mogelijk zijn. Orgaan- en stamceltransplantatie kent vele aspecten. Eén van die aspecten is het begrijpen van HLA en HLA polymorfisme. Een ander aspect is het definiëren van risicofactoren voor rejectie in orgaantransplantatie, graft-versus- host ziekte in stamceltransplantaties en transplantatie-gecorreleerde complicaties. Een andere belangrijke risicofactor is de ontrouw aan het innemen van de medicatie. Van de volwassen getransplanteerde nierpatiënten houdt 22\% zich niet aan medicijninname en allen hebben afstotingsreacties, hetgeen in zelfs $36 \%$ van deze gevallen resulteert in verlies van de getransplanteerde nier. De psycho-sociale aspecten die aan dit gedrag ten grondslag liggen moeten bestudeerd worden om patiënten de juiste begeleiding te kunnen bieden om afstoting en onnodig verlies van organen te voorkomen. Het medicijngebruik en de belasting voor de getransplanteerde patiënten mag hierin niet onderschat worden. Effectief verlagen en kritisch kijken naar mogelijkheden voor minimalisering van medicatie, zoals in Maastricht gehanteerd wordt, kan verder onderbouwd worden met genetische factoren voor medicijn metabolisme.

Het tekort aan donoren is evident gezien de wachtlijst. De toename van donatie bij leven, gestimuleerd door een tekort aan postmortale nieren en betere, minder belastende operatietechnieken, voorkomt een daling van het totaal aantal transplantaties. De beschikbaarheid van postmortale organen kan verbeterd worden. Slechts $53 \%$ van de Nederlandse bevolking heeft zich geregistreerd in het donorregister. Dat betekent dat, zoals $U$ hier zit, Uw Nederlandse buurman of buurvrouw, of zeer waarschijnlijk zijn of haar buurman of buurvrouw zich niet geregistreerd heeft als $U$ dat wel heeft gedaan. De actie Teuntje heeft 
aangetoond dat velen over nadere informatie willen beschikken voordat zij een besluit kunnen nemen. We moeten dat respecteren en de gelegenheid bieden nadere informatie in te winnen. Ik ben van mening dat er naast de keuzes: ja, nee, óf nabestaanden óf een specifiek persoon beslissen, een vijfde categorie toegevoegd moet worden. Deze vijfde categorie moet met name naar aanleiding van de bevindingen van Teuntje de mogelijkheid bieden om nadere informatie op te kunnen vragen en eventueel later te beslissen. Ook hier geldt: je gaat het pas zien als je het door hebt.

Van degenen die hun besluit geregistreerd hebben geeft $57 \%$ toestemming voor het gebruik van organen na overlijden. Indien de beslissing aan de nabestaanden overgelaten wordt, geeft 80\% geen toestemming, waarschijnlijk vanwege onduidelijkheid over wat de persoon in kwestie had gewild. Van de 656 potentiële postmortale donoren in 2007 werd 41\% aangeboden bij de Nederlandse Transplantatie Stichting waarvan $85 \%$ werd getransplanteerd. 386 (59\%) organen werden niet benut. De ziekenhuizen en transplantatieteams kunnen meer patiënten transplanteren als wij ze daartoe in staat stellen.

Het register voor stamceldonoren bevat bijna 13 miljoen donoren. Ik heb $U$ aangegeven dat ondanks dit grote aantal voor $35 \%$ van de patiënten geen volledig gematchte donor gevonden kan worden. Uitbreiding van deze donorbank is zeer gewenst. Het aantal geregistreerde stamceldonoren is beperkt. Vooral wil ik de aandacht vestigen op het aantal geboortes in Nederland, bijna 180.000 in 2007, terwijl er slechts 3668 navelstreng donoren geregistreerd zijn.

Bij de in Maastricht ontwikkelde en geïntroduceerde Cardio stick staat de patiënt centraal. Deze tools kunnen breder toegepast worden. Individualisering van patiëntspecifieke informatie voor patiëntgerichte geneeskunde moet realiseerbaar zijn. Gegevens over HLA polymorfismen en pharmacogenomische SNP informatie, die bijvoorbeeld effectiviteit van medicijnen beïnvloeden, zijn ook van belang voor iedereen. Laten we daar de donorregistratie bij opnemen.

Mijnheer de rector, dames en heren; ik vertrouw erop dat $U$, gezien uw aandachtige blikken, deze rede niet ervaren heeft als een voorleesuurtje en $U$ in ieder geval gemotiveerd heeft te registreren voor orgaan- en weefseldonatie; ook al weet $u$ nu uw keuze nog niet. Neem in ieder 
geval uw eigen besluit en laat $U$ zich niet door de politiek een algemeen standpunt opleggen. Geen reactie leidt tot een verwarde politieke discussie door speculaties over en extrapolaties van onduidelijke gegevens. Dit zal gezien de diversiteit van perceptie, de heterogeniteit en cultuurverschillen binnen de Nederlandse bevolking hooguit tot een politieke aanbeveling leiden. Als $U$ dan toch aan het denken bent gezet, overweeg $U$ aan te melden als bloeddonor, als stamceldonor en laat de stamcellen uit navelstrengbloed ten gunste komen van degenen die het nu nodig hebben.

\section{Onderwijs}

Dames en heren studenten: de Universiteit Maastricht: leading in learning; Velen zijn u voorgegaan in het bewerken van risicovolle projecten, de zogenaamde alles of niets projecten. Een paar voorbeelden heb ik genoemd. In de Transplantatie Immunologie kunt u zich op alle gebieden bekwamen; klinisch toegepast en fundamenteel, technologisch en theoretisch, beta en gamma; ik ken geen veelzijdiger vakgebied dan de Transplantatie Immunologie. Dames en heren topsporters onder $U$ zijn ten zeerste welkom. Uw uitstekende capaciteit om goed te plannen leidt tot een kritisch en efficiënt omgaan met de tijd en bent $U$ minstens zo productief als Uw niet-sportende collega's. Artsen, arts-onderzoekers, assistenten en allen die betrokken bij transplantaties zijn; Transplantatie Immunologie kent vele kanten, mijn kant zal ik U met plezier doceren.

\section{Epiloog}

Soms wordt serologie als kunst beschouwd; hetgeen mijn inziens gerelateerd is aan de interpretatie ervan, wat inderdaad een kunststukje is. Het gevoel voor sequencen en sequentie analyses kreeg ik van onze minister van Onderwijs, Cultuur en Wetenschap minister Plasterk, die "mooie sequentie gels las als poëzie". Het belang van sequentie informatie is hem niet vreemd en ik vertrouw erop dat hij deze culturele inspanning als direct klinisch relevant toegepast translationeel onderzoek beschouwt en subsidieert. Dit onderzoek is letterlijk direct toepasbaar "from bench to bedside". Misschien helpt het poëtische citaat: "listening to silence and understanding nonsense" van collega Cartegni waarmee hij een grote subsidie voor onderzoek binnenhaalde, ook hem over de drempel. 


\section{Dankwoord}

Mijnheer de Rector Magnificus, leden van de Raad van Bestuur van het Maastricht Universitair Medisch Centrum en in het bijzonder Guy Peeters, de stichting Annadal, leden van het College van Bestuur van de Universiteit Maastricht, de Decaan en voormalig Decaan van de Faculty of Health Medicine and Life Sciences, ik dank $U$ allen voor het in mij gestelde vertrouwen op basis waarvan $U$ mij benoemd heeft tot bijzonder hoogleraar Transplantatie Immunologie. De Raad van Toezicht dank ik voor hun advies en ondersteuning; mijn collegae afdelingshoofden van de RVE's in het bijzonder de RVE laboratoria en ondersteunende afdelingen, waarbij ik me meteen thuis voelde. De klinische afdelingen en afdelingshoofden waarbij het Laboratorium Weefseltypering direct betrokken is; de plezierige samenwerking en kritische interactie wordt gewaardeerd.

Hooggeleerde Van Rood, beste Jon. Ik begon mijn rede met een verwijzing naar jouw pionierswerk. Jon van Rood, arts en onderzoeker. .ik doe je tekort, je bent zoveel meer. Ik heb niet alleen de wetenschappelijke benaderingen en expertise van je geleerd maar onder andere ook vele politieke en sociale aspecten van het onderzoek leren kennen. Ik ben je er dankbaar voor en ben er trots op dat je mij als je wetenschappelijke zoon beschouwt.

Oud-analisten, studenten, promovendi; jullie dynamiek, doorzettingsvermogen, motivatie en enthousiasme hebben een belangrijke bijdrage aan mijn carrière geleverd. Ik zou vele namen kunnen noemen maar dat doe ik niet; allen zijn jullie mij dierbaar. Als uitzondering noem ik wel Anette van Dijk; samen hebben we veel bereikt en de Transplantatie Immunologie met onze expertise en kennis een groot gezicht gegeven. Ella van den Berg-Loonen wil ik bedanken voor de samenwerking waardoor wij Sequencing Based Typing tot De Gouden Standaard hebben weten te maken. Je hebt een kwaliteitslaboratorium neergezet dat mij nu vele mogelijkheden biedt om mijn ambities te realiseren. Postdocs, AIO's, studenten en vooral ook de analisten van het Laboratorium Weefseltypering. Het was even wennen en mijn benadering is voor jullie nog niet altijd even duidelijk. Jullie hebben je in één jaar vele nieuwe bepalingen, benaderingen en verantwoordelijkheden eigen gemaakt. Soms met kunst en vliegwerk maar het heeft jullie en mijn kennis vergroot en de patiëntenzorg een nieuwe dimensie gegeven. Voor HLA 
moet je gevoel hebben en ik heb ervaren dat ieder van jullie een HLA-, of misschien beter gezegd een Transplantatie Immunologie-man of vrouw is. Jullie zijn een essentiële groep, zonder jullie loopt de diagnostiek en research niet en kan ik geen nieuwe paden inslaan. Het is mij een eer om met jullie het Transplantatie Immunologie Maastricht, het TIM-team te vormen. Met name wil ik Christien Voorter en Diana van Bakel noemen. Jullie ondersteuning vanaf het begin dat ik de leiding had waardeer ik enorm. Jullie hebben mij in het azM en Laboratorium Weefseltypering wegwijs gemaakt en ik zie er naar uit nog lang met jullie samen te werken.

Verschillende maatjes uit mijn studietijd zijn er helaas niet meer, noch mijn vader, noch mijn schoonvader die hier fier zou rondlopen. Gelukkig zijn mijn moeder en schoonmoeder er vandaag wel bij; mijn dank gaat naar hen uit voor de ondersteuning maar vooral hun trots dat ik hier nu sta. En dan het belangrijkste, ons gezin: Charlotte en Liesbeth; wat wil ik nog meer dan twee fantastische meiden. leder van jullie heeft op eigen wijze aan mijn carrière bijgedragen. Dat geldt ook voor Rietje. De vrijheid die je mij geeft om mijn ambities te realiseren en toestaat zoveel tijd aan deze hobby te besteden, je steun en ondersteuning op velerlei wijze, waardeer ik enorm. Ik bewaar vele herinneringen in mijn hart, en die blijven van ons.

Ik heb gezegd.

De volgende bedrijven wil ik hartelijk danken voor hun financiële bijdrage voor de uitgave van deze oratie: Idion, Tepnel, Roche Molecular Systems, Luminex, BD Biosiences, Roche Diagnostics en het MECC. 


\section{Bronvermelding}

Brouard S. et al. Identification of a peripheral blood transcriptional biomarker panel associated with operational renal allograft tolerance. PNAS, 2007, 104: 15448-15453.

Bulletin van Botanische tuinen: 51, 2007.300 jaar Linnaeus

Cano P. et al. Common and well-documented HLA alleles, Hum Immunol, 2007, 68: 392-417.

Cartegni L. et al. Listening to silence and understanding nonsense: exonic mutations that affect splicing. Nature Reviews Genetics, 2002, $3: 285-298$.

El-Awar N. et al. Epitopes of the HLA-A, B, C, DR, DQ and MICA antigens. Clin Transplantation, 2007; 175 -194.

Geraghty D. et al. Complete sequence and gene map of a human major histocompatibility complex. The MHC sequencing consortium. Nature, 1999, 921-923.

Hansen R. et al. Medication adherence in chronic disease: issues in posttransplant immunosuppression. Transplant Proc, 2007, 39: 12871300.

Heemskerk M.B.A. et al. Highly diverged MHC class I mismatches are acceptable for haematopoietic stem cell transplantation. Bone Marrow Transpl, 2007, 40: 193-200.

Horton R. et al. Variation analysis and gene annotation of eight MHC haplotypes: The MHC haplotype project, Immunogenetics, 2008, 60: 1-18.

Lao O. et al. Correlation between genetic and geographic structure in Europe. Current Biology, 2008, 18: 1-8.

MacDonald W.A. et al. A naturally selected dimorphism within the HLA-B44 supertype alters class I structure, peptide repertoire, and T cell recognition. J Exp Med, 2003, 198: 679-691. 
NTS Orgaan- en weefseldonatie en -transplantatie in Nederland, 2007

NTS jaarverslag 2007, online 2008

Van Rood J.J. Leukocyte grouping, a method and its application. Thesis 1962

Takahashi K. et al. Induction of pluripotent stem cells from adult human fibroblasts by defined factors. Cell, 2007, 131: 861.

Traherne J.A. et al. Genetic analysis of completely sequenced diseaseassociated MHC haplotypes identifies shuffling of segments in recent human history. PLOS Genetics, 2006, 2: 81-92.

Vlaminck $\mathrm{H}$. et al. Prospective study on late consequences of subclinical non-compliance with immunosuppressive therapy in renal transplant patients. Amer J Transpl, 2004, 4: 1509-1513.

Wheeler D.A. et al. The complete genome of an individual by massively parallel DNA sequencing. Nature, 2008, 452: 872-877.

Bone marrow donors worldwide: www.bmdw.org

Immunogenetics database: www.ebi.ac.uk/imgt/hla/

Nationaal instituut voor gezondheidsbevordering en ziekte preventie: www.nigz.nl

NIGZ donorvoorlichting: www.donorvoorlichting.nl 
